Article

\title{
A Hybrid Multi-Criteria Approach for Evaluation and Selection of Sustainable Suppliers in the Avionics Industry of Pakistan
}

\author{
Noor Muhammad ${ }^{1, *(\mathbb{C}, \text { Zhigeng Fang }}{ }^{1}$, Syed Ahsan Ali Shah ${ }^{2}$ (), Muhammad Azeem Akbar ${ }^{3}$, \\ Ahmed Alsanad ${ }^{4, *}$, Abdu Gumaei ${ }^{4}(\mathbb{D})$ and Yasir Ahmed Solangi ${ }^{2}(\mathbb{D})$ \\ 1 College of Economics and Management, Nanjing University of Aeronautics and Astronautics, \\ Nanjing 210016, China; Zhigengfang@163.com \\ 2 School of Economics and Management, Nanjing University of Science and Technology, Nanjing 210016, \\ China; ahsan.shah1@hotmail.com (S.A.A.S.); yasir.solangi86@hotmail.com (Y.A.S.) \\ 3 College of Computer Science and Technology, Nanjing University of Aeronautics and Astronautics, \\ Nanjing 210016, China; azeem.akbar@ymail.com \\ 4 STC's Artificial Intelligence Chair, Department of Information Systems, College of Computer and \\ Information Sciences, King Saud University, Riyadh 11451, Saudi Arabia; abdugumaei@gmail.com \\ * Correspondence: noor@nuaa.edu.cn (N.M.); aasanad@ksu.edu.sa (A.A.)
}

Received: 19 February 2020; Accepted: 3 June 2020; Published: 10 June 2020

\begin{abstract}
Reliability and quality are the two ultimate objectives in the avionics industry. The risk of counterfeit electronics and the unavailability of screening facilities for 100\% components are the most concerning areas in the supply chain of the avionics industry. Unlike most public procurement, the cost is not the only significant criterion. Unbiased decision-making criteria to accommodate all the important factors without compromising on quality, reliability, and maintainability are essential for the evaluation and selection of sustainable suppliers. Therefore, this study proposes an unbiased decision methodology based on the fuzzy analytic hierarchy process (FAHP) and the fuzzy technique for order performance by similarity to ideal solution (FTOPSIS). In the first phase, six main and twenty-one sub-criteria are selected from the literature and empirically validated by experts of the avionics industry. FAHP is used to evaluate the weight of the main criteria and sub-criteria. FTOPSIS is used to prioritize eight alternatives (suppliers) concerning their effectiveness and superiority in finding the best alternatives. The results of the FAHP reveal that traceability $(\mathrm{T})$ is the most important criterion, followed by quality $(\mathrm{Q})$, and cost $(\mathrm{C})$, which rank as the second and third most significant criteria. The results of the FTOPSIS rate supplier 8, supplier 2, and supplier 1 as the first, second, and third most effective suppliers, respectively.
\end{abstract}

Keywords: counterfeit electronics; sustainable supplier selection; reliability; avionics industry; FAHP; FTOPSIS

\section{Introduction}

Avionics is mostly used for flight-worthy electronics. All electronic and electrical assemblies or systems of flying objects are termed as avionics. The avionics industry contributes to the field of aviation (Boeing, AirBus, and now Comac by China, etc.), space exploration like National Aeronautics and Space Administration (NASA), China National Space Administration (CNSA), European Space Agency (ESA), Indian Space Research Organization (ISRO), and Space and Upper Atmosphere Research Commission (SUPPARCO), etc., and defense (fighter jets, helicopters, unmanned aerial vehicles (UAVs), missiles, rockets, etc.). Avionics functions as the brain of all such products and is responsible for reliable operations. Due to the application and safety requirements, all avionics products demand 
high reliability. In developing countries, the avionics industry is either confined to the repair and maintenance of commercial aircraft and other aviation equipment like helicopters, personal jets, or linked to the defense industry, which relies on imports of electronic components and parts [1].

The avionics industry in Pakistan is one of the largest manufacturing and production setups in the country, satisfying the needs of the defense or military avionics and aerospace programs of the country. The quality of a product and its reliability depends upon its design, production process, and the material used [2]. Mechanical and chemical materials have limited variety, and testing facilities are mostly available to verify mechanical, chemical, and compositional properties. For these types of materials, the most sustainable supply chain is established due to the involvement of more suppliers and unchanging requirements. Electronic components are diverse in their type, functionality, and testing requirements; therefore, it is not possible to establish a testing facility for each electrical/electronic component. The risk of the supply of counterfeit electronic components is a major threat to product quality, reliability and failure due to the fact that a small component can be very costly and risky. The identification of counterfeit electronic components, during or before assembly, is not possible and can only be assured through a reliable and sustainable supply chain $[3,4]$. The failure of the end product is usually many times more expensive than the component $[5,6]$. The conventional lowest bidder procurement criteria are a Spartan threat to product quality and reliability, especially in the supply of electronic components. A resilient and sustainable supply chain of electronic and electrical components is required for the avionics industry in order to mitigate risk, safety, quality, and reliability issues. Therefore, the suppliers and vendors in the avionics industry for the supply of electronic and electrical parts must aim for quality, reliability, traceability, and serviceability, while keeping in view long lifecycle support for the avionics industry [6-8].

Different researchers have discussed the threat of counterfeit electronics in relation to product quality and reliability. However, to the best of our knowledge, none of the studies have provided a solution to the problem being faced by the high-tech avionics industries of developing countries. Similar studies have been conducted for the automobile, steel, and home appliance industries, but the objective has been the minimization of the cost and just-in-time (JIT) continuity of supply [9-13]. This study is the first of its kind, targeting avionics industries in developing countries that have to rely on imports of electronic parts and assemblies. This study provides a roadmap to mitigate the threat of counterfeit electronics, to avoid mission failures, and improve quality and reliability. Supplier selection is a multi-faceted strategic decision, but in the literature, and to the best of our knowledge, there exists a gap in relation to the use of multi-criteria decision making (MCDM) with the fuzzy analytical hierarchy process (FAHP) and fuzzy technique for order performance by similarity to ideal solution (FTOPSIS) techniques to identify and prioritize factors like sustainability, quality, reliability, and risk simultaneously, as most of the studies have focused on cost and time of delivery in supplier selection $[14,15]$.

This finding provides comprehensive selection criteria for a sustainable supplier of electronic components based on cost, traceability, quality, warranty/guaranty, and risk. In the first instance, this study proposes the FAHP to determine the preferred weighting of criteria and sub-criteria for supplier selection. Secondly, the FTOPSIS method is used to rank alternatives precisely (suppliers) for the avionics industry of Pakistan. The fuzzy set theory helps to minimize the uncertainty in determining the decision-making problem, since it is difficult to obtain significant findings using simple AHP and TOPSIS methods. Therefore, the fuzzy-based approach helps to estimate exact numerical values and minimize the errors made by experts during decision making.

Finally, the feasibility of the proposed model is analyzed, and a sensitivity analysis is conducted, which shows that the model can cater to different scenarios. The final evaluation is consistent for supplier selection under different input parameters. The study is applicable to similar situations where a decision regarding the supply chain involves criteria other than cost, time and quality, and also for developing countries for which the avionics production setup relies on the import of reliable electronic components $[16,17]$. 
To address the study objective, we have developed the following research questions (RQs):

RQ1: What are the criteria and sub-criteria for supplier selection reported in the literature?

RQ2: What do the experts really think about the criteria and sub-criteria of supplier selection identified from the literature?

RQ3: What would be the prioritization-based taxonomy of the identified criteria and sub-criteria?

RQ4: How do we investigate the best supplier?

The following is the organization and sequence of this research work: Section 2 contains a research background; Section 3 presents the methodology; Section 4 presents the study findings, results and discussion Section 5 presents the conclusion of the study.

\section{Research Background}

This section provides a detailed research background on the supplier selection based on various important criteria and sub-criteria, since supplier selection is a strategic problem in any industry for its sustainable development. This section identifies the research gap for carrying out this research.

\subsection{Supplier Selection Concept}

Sustainable supplier selection is the process of finding suitable suppliers under given constraints and objectives who can provide desired quality products or services at a prescribed time frame without affecting the production cycle, quality, and quantity of products being manufactured. In the literature [18,19], the process consists of the following stages:

a. Initial screening of suppliers from a group consisting of a large number of suppliers to squeeze or shortlist the alternatives to avoid tedious calculations.

b. Finalize selection criteria for supplier selection, based on specific parameters like cost, quality, traceability, delivery, and agility.

c. Continuous evaluation and assessment of suppliers and the identification of sustainable suppliers.

Due to the high reliability of end products, it is necessary to carry out decision making at this point to avoid costly failures. Alikhani et al. [20] studied strategic supplier selection under sustainability and risk assessment. They developed the model for both risk-neutral and risk-averse decision-makers through the classification of suppliers by risk assessment. Memari et al. [21] employed a fuzzy TOPSIS approach to select a suitable supplier that satisfies both main and sub-criteria. Chamodrakas et al. [22] used fuzzy AHP to evaluate available information in the electronic market place to evaluate the suppliers without human biases. Settanni et al. [23] performed their research on the effectiveness of the product-service system (PSS) that is difficult to obtain from the analysis of field reliability data alone in the avionics industry. They further discussed long-term cooperation with suppliers regarding availability based contracts in the avionics industry. Wagner and Friedl [24] suggested supplier development strategies and their performance implication for product development and lifecycle. The idea is to work either on direct or indirect supplier development to facilitate high tech industrial setup like the avionics industry. Lintukangas et al. [25] discussed the role of supply management innovativeness and supplier orientation in firms' sustainability performance. Gören, H. [26] developed a decision framework for sustainable supplier selection and order allocation.

\subsection{Applications of MCDM Used in Supplier Selection}

MCDM is an effective approach to address the complex decision making problems regarding supplier selection and offer direction for a sustainable, cost-effective, agile, and reliable methodology for supplier selection in the avionics industry [18,21,27]. Several MCDM approaches exist, such as: AHP, ELimination Et Choice Translating Reality (ELECTRE), the Analytic Network Process (ANP [28], Data Envelopment Analysis (DEA) [29,30], Weighted Aggregated Sum-Product Assessment 
(WASPAS) [31], Additive Ratio Assessment (ARAS), the Best Worst Method (BWM), VlseKriterijuska Optimizacija I Komoromisno Resenje (VIKOR), and TOPSIS method which can be used for supplier selection [32]. The FAHP is widely used in multi-criteria decision-making problems in order to mitigate human errors in dealing with linguistic values. A few examples of widely used FAHP applications include supplier selection in the automotive industry, supplier selection in the Iran steel industry using the AHP and TOPSIS approaches [9], quality of service, and catering evaluation of airlines [33,34], product or service performance evaluations [35], and finalizing alternative ranking in the energy sector [36,37]. Comparison of the FAHP and FTOPSIS methods of sustainable supplier selection shows that both methods are suitable for the problem of supplier selection; the FTOPSIS method is better suited to the problem of supplier selection for changing alternatives and criteria, as it provides more agility, while FAHP reduces the fuzziness in assigning weights to the different main criteria and sub-criteria. In the literature, there are various review studies which have used MCDM methods to evaluate the supplier selection problem.

Although each and every study has a different aim and objective to solve the decision problem, Table 1 presents the recent studies of supplier selection and evaluation problems in the context of various industries.

Table 1. The recent studies on the supplier selection and evaluation problem using multi-criteria decision making (MCDM) methods.

\begin{tabular}{|c|c|c|c|c|}
\hline Study Objective & Industry & Method & Year & Reference \\
\hline Green supplier selection & Manufacturing & TOPSIS & 2016 & [38] \\
\hline $\begin{array}{l}\text { Supplier selection based on green innovation } \\
\text { ability }\end{array}$ & Manufacturing & $\begin{array}{l}\text { FAHP and } \\
\text { TOPSIS-Grey }\end{array}$ & 2020 & [39] \\
\hline Supplier selection & Food & BWM & 2016 & [40] \\
\hline Green supplier selection & Textile & FAHP & 2019 & [41] \\
\hline Green supplier selection & Cement & AHP & 2016 & [42] \\
\hline Reverse logistic partner & Manufacturing & TOPSIS & 2016 & [43] \\
\hline Sustainable supplier selection & Automobile & AHP and VIKOR & 2017 & [44] \\
\hline Green supplier selection & Electronic & $\begin{array}{l}\text { AHP and } \\
\text { ELCTRE }\end{array}$ & 2014 & [45] \\
\hline Technology selection & Engineering & ANP & 2014 & [46] \\
\hline Global Supply Chain & Logistics & FAHP and FANP & 2011 & [47] \\
\hline Safety and health management & Government & ANP and VIKOR & 2016 & [48] \\
\hline Green operations initiatives & Manufacturing & TOPSIS & 2015 & [49] \\
\hline Supply chain performance & Manufacturing & TOPSIS & 2014 & [50] \\
\hline Assessment of green supplier problem & $\begin{array}{l}\text { Supply chain } \\
\text { industry }\end{array}$ & Fuzzy WASPAS & 2019 & [51] \\
\hline Green Supplier Selection & Steel & $\begin{array}{l}\text { BWM and } \\
\text { FTOPSIS }\end{array}$ & 2020 & [52] \\
\hline $\begin{array}{l}\text { Green supplier selection for sustainable } \\
\text { development }\end{array}$ & Automobile & $\begin{array}{l}\text { DEMATEL and } \\
\text { ANP }\end{array}$ & 2018 & [53] \\
\hline Supplier selection & Washing Machine & FAHP & 2011 & [12] \\
\hline Long Term Supplier Selection & Telecommunication & FTOPSIS & 2008 & [54] \\
\hline Supplier Development & Manufacturing & FAHP & 2011 & [55] \\
\hline Supplier Selection and Performance Evaluation & Automobile (CAR) & $\begin{array}{l}\text { FAHP, FTOPSIS } \\
\text { and DEA }\end{array}$ & 2011 & [56] \\
\hline
\end{tabular}

It has been identified from the previous studies that MCDM methods are beneficial in identifying, analyzing, and prioritizing the supplier selection in the context of different industries. The purpose of 
each research or decision problem has been evaluated on multi-criteria analysis. However, this study contributes to the state of the art by proposing a research model based on FAHP and FTOPSIS to assess the supplier selection problem in the context of the avionic industry of Pakistan. This study aims to identify and assess the main criteria and sub-criteria for analyzing the suitable supplier using the FAHP method. Then, these identified criteria and sub-criteria are used in the FTOPSIS methodology to select the supplier for the avionic industry in Pakistan. This study shall assist industry managers and practitioners in adopting critical criteria and sub-criteria for supplier selection.

\section{Research Methodology}

The study aims (1) to identify the criteria and sub-criteria from the literature and validate them with experts from industry and academia using the questionnaire survey approach, (2) to prioritize the identified criteria and sub-criteria concerning to their significance for the sustainable selection by applying the step-by-step mechanism of fuzzy AHP, (3) and to prioritize the supplier section using the fuzzy TOPSIS approach. To address the objective of the research, the proposed methodology is presented in Figure 1 and briefly discussed in the subsequent section.

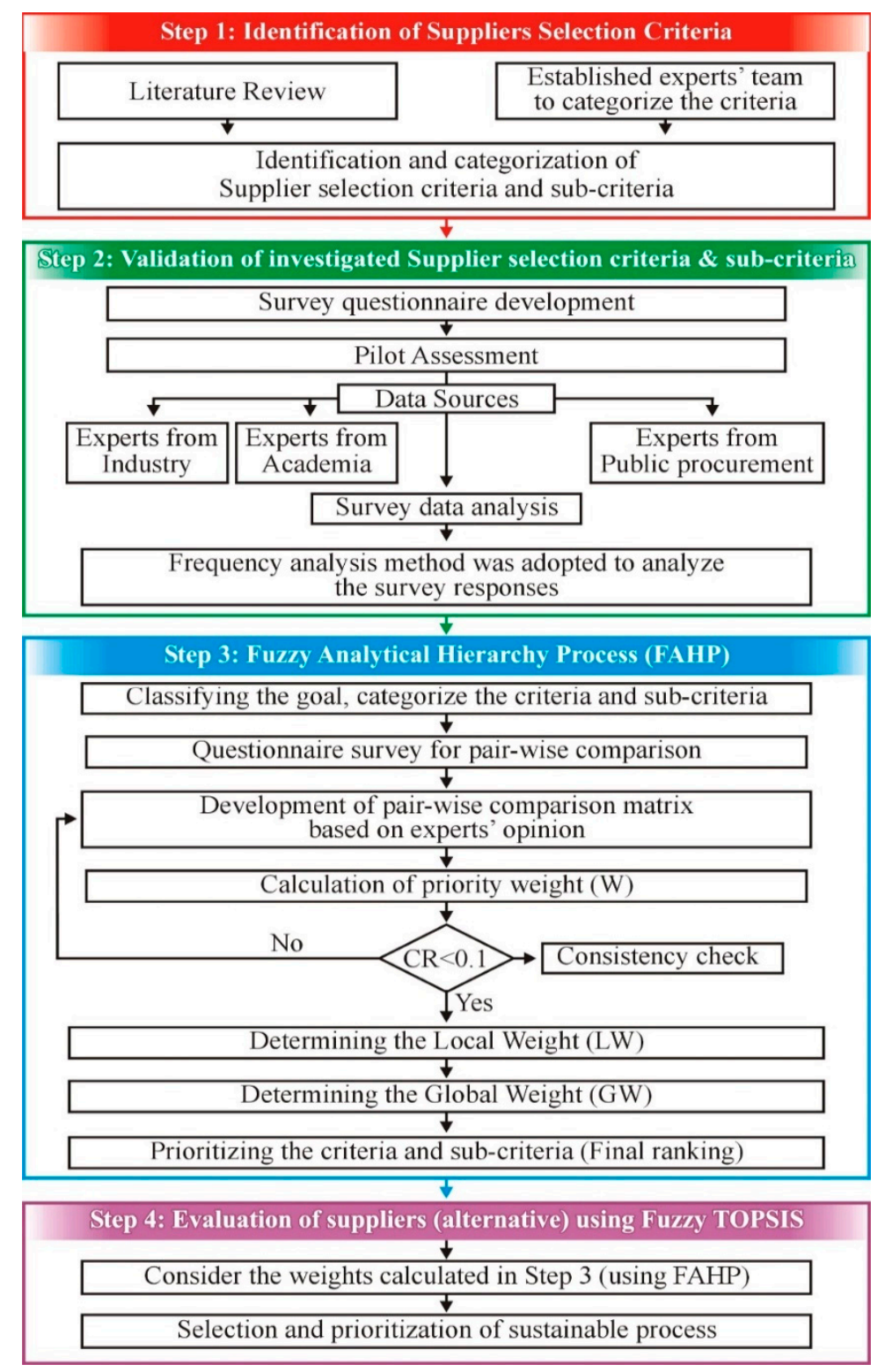

Figure 1. Proposed Research Methodology. 


\subsection{Identification of Main Criteria and Sub-Criteria for Supplier Selection}

\subsubsection{Literature Review on the Selection of Criteria and Sub-Criteria}

The existing literature related to the study objective was collected and reviewed to extract different criteria and sub-criteria for supplier selection in various industries and its relevancy with the objective of this research work. The collection of appropriate and valid literature is significant. Considering the suggestions of Chen et al., and by considering the research experiences of our research team, we reviewed "IEEE Xplore," "Science Direct," "MDPI Digital Library," "Springer Link," "Wiley Inter-Science," and "Google Scholar". The key terms used in the research questions were executed on the selected databases to explore the literature related to the study objective. The authors of this study and industry experts shortlisted the selection criteria and sub-criteria in order to remain concise in criteria selection and avoid irrelevant factors. The experts have 10+ years of experience in procurement and supply chains and are well aware of issues regarding our objective being the front end of problems of the industry. Finally, the selected criteria and sub-criteria were evaluated by industry experts and researchers with direct experience of the production, quality, and reliability of high-tech avionic products. The selected criteria and sub-criteria are briefly explained in Table 2.

Table 2. Main criteria and sub-criteria selected from the literature.

\begin{tabular}{|c|c|c|c|c|}
\hline Criteria & Sub-criteria & Code & Explanation & Reference \\
\hline \multirow{2}{*}{ Cost $(C)$} & $\begin{array}{c}\text { Price } \\
\text { Variations }\end{array}$ & $\mathrm{C} 1$ & $\begin{array}{l}\text { Unnecessary price variation with time demonstrates } \\
\text { weak principle suppliers and weak reliability. }\end{array}$ & \multirow{2}{*}[11,14,21,30,55-59]{} \\
\hline & $\begin{array}{l}\text { Minimum } \\
\text { Order } \\
\text { Quantity }\end{array}$ & $\mathrm{C} 4$ & $\begin{array}{l}\text { Stockists mostly do not impose minimum order quantity } \\
\text { (MOQ) conditions, while resellers always demand MOQ. } \\
\text { MOQ restrictions can increase cost significantly in } \\
\text { avionic industry. }\end{array}$ & \\
\hline \multirow{4}{*}{ Traceability (T) } & Mouser & $\mathrm{T} 2$ & $\begin{array}{l}\text { Traceability towards reliable electronic component stockist } \\
\text { and supplier. }\end{array}$ & \multirow{4}{*}[2,3,60-62]{} \\
\hline & Arrow & T3 & $\begin{array}{l}\text { Traceability towards reliable component stockist } \\
\text { and supplier. }\end{array}$ & \\
\hline & Farnell & $\mathrm{T} 4$ & $\begin{array}{l}\text { Traceability towards reliable component stockist } \\
\text { and supplier. }\end{array}$ & \\
\hline & OEM & T5 & $\begin{array}{l}\text { Traceability towards original equipment manufaturer (OEM) } \\
\text { mitigates the doubts of fake or counterfeit. }\end{array}$ & \\
\hline \multirow[t]{2}{*}{ Quality (Q) } & $\begin{array}{c}\text { OEM } \\
\text { Certificates }\end{array}$ & Q3 & Authenticates the OEM and its quality standards. & \multirow[t]{2}{*}[3,10,11,13,63,64]{} \\
\hline & $\begin{array}{l}\text { Equivalency } \\
\text { certificate }\end{array}$ & Q4 & $\begin{array}{l}\text { Required only in case of replacements of parts due to the } \\
\text { obsoleteness or availability of the next version. }\end{array}$ & \\
\hline
\end{tabular}


Table 2. Cont.

\begin{tabular}{|c|c|c|c|c|}
\hline Criteria & Sub-criteria & Code & Explanation & Reference \\
\hline \multirow{4}{*}{ After Sales (AS) } & Warranty & AS1 & Ability to respond or replace if the product or module fails. & \multirow{4}{*}[16,23,65]{} \\
\hline & $\begin{array}{l}\text { Previous } \\
\text { Experience }\end{array}$ & AS2 & Fulfillment of warranty and guarantee if required in the past. & \\
\hline & $\begin{array}{l}\text { Market } \\
\text { Reputation }\end{array}$ & AS3 & $\begin{array}{l}\text { Input from sister organizations and other customers about } \\
\text { the supplier. }\end{array}$ & \\
\hline & $\begin{array}{l}\text { Performance } \\
\text { Bond }\end{array}$ & AS4 & Surety provided for warranty period. & \\
\hline \multirow{3}{*}{ Risk (R) } & $\begin{array}{l}\text { Lack of } \\
\text { capability }\end{array}$ & R1 & $\begin{array}{l}\text { Has participated in the procurement procedure, won the } \\
\text { order, and is unaware of difficulties and limitations due to } \\
\text { weak principle links. }\end{array}$ & \multirow{3}{*}[3,4,8,20,25,66]{} \\
\hline & Counterfeit & $\mathrm{R} 2$ & It provides a copy or fake component in good packing. & \\
\hline & Refurbished & R3 & It provides components that have consumed a useful life. & \\
\hline \multirow{4}{*}{ Delivery (D) } & $\begin{array}{l}\text { Timely } \\
\text { delivery }\end{array}$ & D1 & Timely delivery will help in the execution of the production. & \multirow{4}{*}[11,13,23,64,67]{} \\
\hline & $\begin{array}{l}\text { Delayed } \\
\text { Delivery }\end{array}$ & D2 & Delayed delivery can put production setup on hold. & \\
\hline & $\begin{array}{l}\text { Fail To } \\
\text { Deliver }\end{array}$ & D3 & $\begin{array}{l}\text { Failure to deliver means the whole process is nullified, and } \\
\text { we have to restart from the beginning. High tech production } \\
\text { delays are mostly linked with this issue }\end{array}$ & \\
\hline & $\begin{array}{l}\text { Partial } \\
\text { Delivery }\end{array}$ & (D4) & $\begin{array}{l}\text { A partial order is delivered and a few parts remain pending } \\
\text { for too long, which causes delays in production process. }\end{array}$ & \\
\hline
\end{tabular}

\subsubsection{Data Collection and Analysis of Main Criteria and Sub-Criteria}

In the above phase, the criteria and sub-criteria selected from the literature review were identified and documented in Table 2. The steps adopted to conduct the empirical study are described here. The empirical evaluation of the criteria and sub-criteria identified during the literature study was conducted by developing a survey questionnaire. The questionnaire consists of both open and close-ended questions. The closed-ended section consists of the criteria and sub-criteria collected via a literature review study. In the open-ended section, we requested the survey participants to add the additional criteria which are not enlisted in the close-ended section. The identified criteria and sub-criteria were assessed against the 5-point Likert survey scale: ("strongly agree, agree, neutral, disagree, and strongly disagree"). It is essential to consider the neutral point in the survey evaluation scale because the absence of neutral options could force the respondents to give a biased answer.

In order to validate the questionnaire survey, we conducted a pilot study with the experts of the avionics industry of Pakistan and academia in the field of reliability (National University of Science and Technology, Islamabad, Pakistan, Institute of Space Technologies, Islamabad, Pakistan, Nanjing University of Aeronautics and Astronautics, Nanjing, China), and supply chain department of avionic and defense industry of Pakistan. They have broad research experience in the avionics and aviation field. The experts suggested some structural changes in the questionnaire. They suggested to add the question in tabular form and to put more queries about respondents' bibliographic data. We carefully revised the questionnaire, and the updated questionnaire was used for the data collection process. A sample of the survey questionnaire is given in Appendix A.

\subsubsection{Expert Opinion (Pilot Evaluation of a Survey Questionnaire)}

It is challenging to collect data from the potential population working in high tech industries as they usually avoid sharing such information. The population was approached via a personal relation of our research team and using the snowballing approach. The snowballing approach is an effective way to target the population related to the study objective [68,69]. The invitation letter, along with a questionnaire survey, was sent via email, and it requested them to share it with their colleagues. A total of 19 responses were collected. All collected responses were manually reviewed to check the incomplete entries. We found one incomplete response and 18 complete responses, which include: 
ten from industry, three from the supply chain, and five from academia. The number of respondents was limited, but their experience and first-hand knowledge of the problem helped in getting a positive response. We also assured the respondents that the collected data will just be used for research purpose, and their identity will remain confidential. The demographic details of the survey participants are provided in Appendix B.

\subsection{Empirical Investigation and Analysis of Criteria and Sub-Criteria}

The frequency analysis method was used to analyze the descriptive data. The frequency analysis approach is helpful in analyzing the ordinal and nominal data across variables or groups of variables. Therefore, a total of 6 criteria and 26 sub-criteria were identified, which will be carefully evaluated using a frequency analysis method to identify the most feasible and important criteria for analyzing the sustainable supplier selection of the avionic industry in Pakistan. The criteria vary according to the situation, the location of production setup, and the international obligations of each country. A developing country might be facing different constraints or restrictions in the supply of high-tech components than most developing countries. The selection criteria have become complicated due to the involvement of different factors, such as technology barriers, international political and social bindings, and end-user agreements, along with common factors such as quality, delivery, cost, and service. So, in supplier selection/evaluation, we have to consider the capability of the supplier to handle these issues, and it should be resourceful enough to provide all types of required equipment necessary for continuous improvement in customer satisfaction, which drives the search for new and better ways to evaluate and select suppliers [66]. Thus, the refined or most significant criteria and sub-criteria have been identified after careful assessment of survey respondents. The findings are presented in the results section.

\subsection{Fuzzy AHP Method}

The AHP was introduced by Thomas L. Saaty [70], and since then, it has been a useful and widely used tool of MCDM. It can solve MCDM problems by creating a functional hierarchy and quantifying decision-makers' priorities for a set of available alternatives or solutions [71]. AHP is used to develop preference weights for each alternative by assigning a numerical value, a language statement, or weights on a ratio scale from decision-makers' opinion or inclination towards a problem. We employ a consistency check to verify the weights allocated among different options or alternatives. We combine fuzzy set theory with AHP because traditional AHP has some limitations, like dealing with an unbalanced judgmental scale, handling ambiguity, and uncertainty associated with human biases and anonymous rankings. FAHP is a more powerful tool to deal with all limitations regarding uncertainties and human factors affecting decision-makers' feedback. Here we used FAHP by introducing fuzziness; the pairwise numeric operates in a matrix using triangular fuzzy number (TFN) to rank suppliers and finalize selection criteria in the avionics industry of Pakistan. FAHP is applied in the following steps [72];

Step 1: Develop the hierarchical structure of the supplier selection problem.

Step 2: Define the scale for the pairwise comparison matrix, as shown in Table 3.

Step 3: Construct the fuzzy performance/decision matrix and choose the appropriate linguistic variables for the alternatives concerning criteria.

$$
\widetilde{A}=\left(\begin{array}{ccccc}
1 & \tilde{a}_{12} & \ldots & \ldots & \widetilde{a}_{1 n} \\
\widetilde{a}_{21} & 1 & \ldots & \ldots & \widetilde{a}_{2 n} \\
\ldots & \ldots & \ldots & \ldots & \ldots \\
\ldots & \ldots & \ldots & \ldots & \ldots \\
\widetilde{a}_{n 1} & \widetilde{a}_{n 2} & \ldots & \ldots & 1
\end{array}\right)
$$


where $\widetilde{a}_{i j}=1$, if $i=j$ and $\widetilde{a}_{i j}=(\widetilde{1}, \widetilde{3}, \widetilde{5}, \widetilde{7}, \widetilde{9})$ or $\widetilde{a}_{i j}=\left(\widetilde{1}^{-1}, \widetilde{3}^{-1}, \widetilde{5}^{-1}, \widetilde{7}^{-1}, \widetilde{9}^{-1}\right)$ if $i \neq j$. When scoring is calculated for a pair, a reciprocal score is automatically given to reverse comparison in the matrix, whereas, if $\widetilde{A}_{i j}$ is a matrix value given to the relationship of components $i$ and $j$, then $\widetilde{A}_{i j}=\frac{1}{\widetilde{A}_{i j}}$.

Step 4: Normalize the fuzzy-decision matrix [73].

$$
\widetilde{A}^{\alpha}=\left(\begin{array}{ccccc}
1 & \widetilde{a}_{12}^{\alpha} & \cdots & \ldots & \widetilde{a}_{1 n}^{\alpha} \\
\widetilde{a}_{21}^{\alpha} & 1 & \cdots & \cdots & \widetilde{a}_{2 n}^{\alpha} \\
\cdots & \cdots & \cdots & \ldots & \cdots \\
\cdots & \cdots & \cdots & \cdots & \ldots \\
\widetilde{a}_{n 1}^{\alpha} & \widetilde{a}_{n 2}^{\alpha} & \cdots & \cdots & 1
\end{array}\right)
$$

where $\widetilde{a}_{i j}=\mu \widetilde{a}_{i j u}^{\alpha}+(1-\mu) \widetilde{a}_{i j u}^{\alpha}$ and $0<\mu \leq 1$, the new normalized fuzzy matrix is given as;

$$
A=\left(\begin{array}{ccccc}
1 & a_{12} & \ldots & \ldots & a_{1 n} \\
a_{21} & 1 & \ldots & \ldots & a_{2 n} \\
\cdots & \ldots & \ldots & \ldots & \ldots \\
\ldots & \ldots & \ldots & \ldots & \ldots \\
a_{n 1} & a_{n 2} & \ldots & \ldots & 1
\end{array}\right)
$$

Step 5: Perform a consistency check. The consistency of each matrix and that of the hierarchy is calculated using the consistency ratio (CR). For calculating CR, we initially calculated the consistency index $(\mathrm{CI})$ as below;

$$
C I=\left(\lambda_{\max }-n\right) /(n-1)
$$

Later, we computed CR as;

$$
C R=C I / R I
$$

where $R I$ is a random index, and its values are given in the Table 3.

Table 3. Values of RI.

\begin{tabular}{ccccccccc}
\hline $\boldsymbol{n}$ & $\mathbf{1}$ & $\mathbf{2}$ & $\mathbf{3}$ & $\mathbf{4}$ & $\mathbf{5}$ & $\mathbf{6}$ & $\mathbf{7}$ & $\mathbf{8}$ \\
\hline$R I$ & 0 & 0 & 0.52 & 0.89 & 1.11 & 1.25 & 1.35 & 1.40 \\
\hline
\end{tabular}

Kong and Liu [74] introduced FAHP, where they replaced membership scales for Saaty's 1-9 scales to decrease adjusting times required and develop a comparison matrix to replace it as shown in Table 4 .

Table 4. Linguistic variable and triangular fuzzy numbers.

\begin{tabular}{ccc}
\hline Number & Linguistic Variable & TFN Scale \\
\hline 1 & Equally important & $(1,1,1)$ \\
\hline 2 & Weakly advantage & $(1,2,3)$ \\
\hline 3 & Not a bad advantage & $(2,3,4)$ \\
\hline 4 & Preferred & $(3,4,5)$ \\
\hline 5 & Good advantage & $(4,5,6)$ \\
\hline 6 & Fairly good advantage & $(5,6,7)$ \\
\hline 7 & Very good advantage & $(6,7,8)$ \\
\hline 8 & Absolute advantage & $(7,8,9)$ \\
\hline 9 & Perfect advantage & $(8,9,10)$ \\
\hline
\end{tabular}




\subsection{Fuzzy TOPSIS Method}

TOPSIS is the methodology of moving closer to a positive ideal solution (i.e., minimizing the gap between criteria) and moving away from a negative ideal solution (maximizing the gap in each criterion) [75]. This method is particularly suitable for solving the group decision-making, problem under fuzzy environment [37]. A combination of fuzzy mathematic with TOPSIS gives us FTOPSIS used to solve decision criteria problems having uncertainty, immeasurable, and incomplete information problem under a fuzzy environment [76]. The following are the main steps of the multi-person, multi-criteria decision-making process with fuzzy TOPSIS for dealing with the supplier selection [35]:

Step 1: Choose the appropriate linguistic variables for the importance weight of selection criteria and the linguistic ratings for suppliers. Table 5 lists the linguistic variable scale.

Table 5. Ratings of linguistic variables.

\begin{tabular}{ccc}
\hline Number & Linguistic Variables & TFNs \\
\hline 1 & Very low (VL) & $(1,2,3)$ \\
\hline 2 & Low $(\mathrm{L})$ & $(2,3,4)$ \\
\hline 3 & Medium low $(\mathrm{ML})$ & $(3,4,5)$ \\
\hline 4 & Medium $(\mathrm{M})$ & $(4,5,6)$ \\
\hline 5 & Medium high $(\mathrm{MH})$ & $(5,6,7)$ \\
\hline 6 & High $(\mathrm{H})$ & $(6,7,8)$ \\
\hline 7 & Very High $(\mathrm{VH})$ & $(7,8,9)$ \\
\hline
\end{tabular}

Step 2: Construct the fuzzy-decision matrix.

Let $\widetilde{X}_{i}=\left(x_{i 1}, x_{i 2}, x_{i 3}\right)$ be a TFN for $i \in I$. Subsequently, normalized the fuzzy number of each $\widetilde{X}_{i}$ is indicated as:

$$
\widetilde{R}=\left[r_{i j}\right]_{m \times n}
$$

where $i=1,2,3, \ldots, m$ and $j=1,2,3, n$.

Step 3: Normalize the fuzzy-decision matrix. Normalization will consider both cost and benefit criteria separately as given below;

Normalization for benefit (Positive) criteria:

$$
r_{i j}=\left(\frac{x_{1 i j}}{x_{3 j}^{*}}, \frac{x_{2 i j}}{x_{3 j}^{*}}, \frac{x_{3 i j}}{x_{3 j}^{*}}\right)
$$

where $x_{3 j}^{*}=\max _{3 i j}$ (Benefit criteria).

Normalization for cost (Negative) criteria:

$$
r_{i j}=\left(\frac{x_{1 j}^{-}}{x_{3 i j}}, \frac{x_{1 j}^{-}}{x_{2 i j}}, \frac{x_{1 j}^{-}}{x_{1 i j}}\right)
$$

$x_{1 j}^{-}=\min x_{1 i j}$ (Cost criteria).

Step 4: Determine the fuzzy positive-ideal solution (FPIS) and fuzzy negative-ideal solution (FNIS).

$$
\begin{aligned}
& \operatorname{FPIS}\left(A^{+}\right)=\left(\widetilde{v}_{1}^{+}, \ldots, \widetilde{v}_{j}^{+}, \cdots, \widetilde{v}_{n}^{+}\right) \\
& \operatorname{FNIS}\left(A^{-}\right)=\left(\widetilde{v}_{1}^{-}, \cdots, \widetilde{v}_{j}^{-}, \cdots, \widetilde{v}_{n}^{-}\right)
\end{aligned}
$$

where $\widetilde{v}_{j}^{+}=(1,1,1) \otimes \widetilde{w}_{j}=\left(l w_{j}, m w_{j}, u w_{j}\right)$ and $\widetilde{v}_{j}^{-}=(0,0,0), j=1,2,3, \ldots, n$. 
Step 5: Calculate the distance of each supplier from FPIS $\left(d_{i}^{+}\right)$and FNIS $\left(d_{i}^{-}\right)$, respectively.

$$
d_{i}^{+}=\left(v_{1}^{*}, v_{2}^{*}, v_{3}^{*}, \ldots, v_{n}^{*}\right)
$$

where $V_{j}^{*}=(1,1,1) j=1,2,3, \ldots, n$.

$$
d_{i}^{-}=\left(v_{1}^{-}, v_{2}^{-}, v_{3}^{-}, \ldots, v_{n}^{-}\right)
$$

where $V_{j}^{-}=(0,0,0) j=1,2,3, \ldots, n$.

Here, the distance between two TFNs $\widetilde{X}=\left(x_{1}, x_{2}, x_{3}\right), \widetilde{Y}=\left(y_{1}, y_{2}, y_{3}\right)$ can be calculated as:

$$
d(\widetilde{X}, \widetilde{Y})=\sqrt{\frac{1}{3}\left[\left(x_{1}-y_{1}\right)^{2}+\left(x_{2}-y_{2}\right)^{2}+\left(x_{3}-y_{3}\right)^{2}\right]}
$$

Step 6: Calculate the closeness coefficients and improve alternatives for achieving satisfaction by continuous iteration for each criterion:

$$
C C_{i}=\frac{d_{i}^{-}}{d_{i}^{+}+d_{i}^{-}}
$$

where $i=1,2,3, \ldots, m, d_{i}^{+}$and $d_{i}^{-}$are the distances from FPIS and FNIS, respectively.

At the fulfillment of steps 1-6, the FTOPSIS method significantly provides the ranking of suppliers (i.e., alternatives) with the distance to a maximal and minimal suitable solution.

\section{Study Findings}

\subsection{Findings of the Main Criteria and Sub-Criteria}

Supplier selection criteria vary from product to product and industry to industry. Key performance indicators for different industries are different depending upon their core business, nature of products, customers, market competition, and end-user requirements. Unlike the consumer goods and services industry, the requirements for the end-users are entirely different in the case of the avionics industry. In particular, the electronic part is considered as the brain of flying objects, and its failure can lead to the failure of the product or mission. In most industrial procurements, the main criteria include the cost, delivery, and continuous supply [74]. In contrast, for high-reliability end products the cost is less significant. Delivery is linked with the capability of the supplier. Traceability and quality are also the main criteria for performance evaluation and ranking of suppliers. From the literature survey and industrial experience, we have selected six criteria (cost, traceability, quality, after sales, risk, and delivery). These criteria are further divided into sub-criteria in order to profoundly investigate the impact of the criteria and sub-criteria of the objective study. A total of 26 sub-criteria have been selected from the literature that can affect our main criteria and objective function.

\subsection{Empirical Investigation and Analysis (Survey Respondents/expert Opinion)}

The questionnaire survey was developed based on the main criteria and sub-criteria identified through the literature review. The collected opinions from the survey participants were categorized as positive (strongly agree and agree), negative (strongly disagree and disagree), and neutral. Table 6 shows the analysis of the participant's opinion. 
Table 6. Analysis of the survey participant's opinions.

\begin{tabular}{|c|c|c|c|c|c|c|c|c|c|}
\hline \multirow{3}{*}{ S. NO } & \multirow{3}{*}{ Factors } & \multicolumn{8}{|c|}{ Empirical Observations $(N=18)$} \\
\hline & & \multicolumn{3}{|c|}{ Positive } & \multicolumn{3}{|c|}{ Negative } & \multicolumn{2}{|c|}{ Neutral } \\
\hline & & S.A & $\mathbf{A}$ & $\%$ & D & S.D & $\%$ & $\mathbf{N}$ & $\%$ \\
\hline $\mathrm{C}$ & Cost $(\mathrm{C})$ & 5 & 7 & 67 & 2 & 2 & 22 & 2 & 11 \\
\hline $\mathrm{C} 1$ & Price Variations (C1) & 5 & 8 & 72 & 1 & 2 & 17 & 2 & 11 \\
\hline $\mathrm{C} 2$ & Agility (C2) & 6 & 5 & 61 & 2 & 1 & 17 & 4 & 22 \\
\hline $\mathrm{C} 3$ & Financial strength (C3) & 5 & 7 & 67 & 2 & 1 & 17 & 3 & 17 \\
\hline $\mathrm{C} 4$ & Minimum Order Quantity (C4) & 3 & 3 & 33 & 4 & 5 & 50 & 3 & 17 \\
\hline $\mathrm{C} 5$ & Mod of Payment (C5) & 2 & 4 & 33 & 6 & 4 & 56 & 2 & 11 \\
\hline $\mathbf{T}$ & Traceability (T) & 8 & 8 & 89 & 1 & 0 & 6 & 1 & 6 \\
\hline $\mathrm{T} 1$ & Digikey (T1) & 8 & 8 & 89 & 1 & 1 & 11 & 0 & 0 \\
\hline $\mathrm{T} 2$ & Mouser (T2) & 8 & 7 & 83 & 1 & 1 & 11 & 1 & 6 \\
\hline T3 & Arrow (T3) & 7 & 7 & 78 & 1 & 1 & 11 & 2 & 11 \\
\hline $\mathrm{T} 4$ & Farnell (T4) & 7 & 6 & 72 & 2 & 1 & 17 & 2 & 11 \\
\hline $\mathrm{T} 5$ & OEM (T5) & 8 & 7 & 83 & 2 & 0 & 11 & 1 & 6 \\
\hline T6 & Others (T6) & 4 & 5 & 50 & 4 & 3 & 39 & 2 & 11 \\
\hline $\mathbf{Q}$ & Quality (Q) & 6 & 7 & 72 & 2 & 1 & 17 & 2 & 11 \\
\hline$\hat{\mathrm{Q} 1}$ & Test reports (Q1) & 7 & 6 & 72 & 2 & 2 & 22 & 1 & 6 \\
\hline Q2 & Quality certificates (Q2) & 6 & 5 & 61 & 3 & 2 & 28 & 2 & 11 \\
\hline Q3 & OEM Certifications (Q3) & 7 & 3 & 56 & 4 & 2 & 33 & 2 & 11 \\
\hline Q4 & Equivalency certificate (Q4) & 4 & 2 & 33 & 5 & 5 & 56 & 2 & 11 \\
\hline$\hat{A S}$ & After Sales (AS) & 3 & 6 & 50 & 5 & 3 & 44 & 1 & 6 \\
\hline AS1 & Guaranty/Warranty (AS1) & 6 & 6 & 67 & 2 & 2 & 22 & 2 & 11 \\
\hline AS2 & Past experience (AS2) & 5 & 5 & 56 & 4 & 3 & 39 & 1 & 6 \\
\hline AS3 & Market reputation (AS3) & 5 & 6 & 61 & 5 & 2 & 39 & 0 & 0 \\
\hline AS4 & Performance Bond (AS4) & 4 & 4 & 44 & 6 & 3 & 50 & 1 & 6 \\
\hline $\mathbf{R}$ & Risk (R) & 5 & 5 & 56 & 4 & 3 & 39 & 1 & 6 \\
\hline R1 & Lack of capability (R1) & 7 & 6 & 72 & 3 & 2 & 28 & 0 & 0 \\
\hline $\mathrm{R} 2$ & Counterfeit (R2) & 6 & 6 & 67 & 3 & 2 & 28 & 1 & 6 \\
\hline $\mathrm{R} 3$ & Refurbished/used (R3) & 6 & 4 & 56 & 4 & 3 & 39 & 1 & 6 \\
\hline D & Delivery (D) & 5 & 5 & 56 & 3 & 3 & 33 & 2 & 11 \\
\hline D1 & Timely delivery (D1) & 6 & 6 & 67 & 3 & 2 & 28 & 1 & 6 \\
\hline D2 & Delayed delivery (D2) & 6 & 5 & 61 & 3 & 2 & 28 & 2 & 11 \\
\hline D3 & Fail to deliver (D3) & 6 & 5 & 61 & 3 & 3 & 33 & 1 & 6 \\
\hline D4 & Partial Delivery (D4) & 5 & 3 & 44 & 4 & 5 & 50 & 1 & 6 \\
\hline
\end{tabular}

The results presented in Table 6 indicate that the majority of the survey respondents agreed with the investigated main criteria and sub-criteria of supplier selection. We noted that the majority of criteria and sub-criteria contain $\geq 50 \%$ results. For a further analysis process, we consider the critical criteria and sub-criteria. According to Akbar et al. [77], a factor is said to be critical in the empirical study if it is cited by $\geq 50 \%$ of the experts. Only the criteria and sub-criteria with a frequency $\geq 50 \%$ were considered for further analysis. In the final analysis, the main criteria and sub-criteria are squeezed to 6 and 21, respectively. In the next section, these main criteria and sub-criteria are analyzed and ranked using the FAHP method.

\subsection{Fuzzy AHP Results}

Now, we apply the developed framework to solve this complex decision problem, which is a sustainable supplier selection criterion for a reliable supplier in the avionics industry of Pakistan. It has been an unsolved issue with no clear solution. However, experts from different departments (both technical and procurement) have gone through long sessions of brainstorming to finalize criteria that provide a fair chance and competition to every alternative without compromising the key features of the quality and reliability of components purchased. 


\subsubsection{Develop the Hierarchy Structure of Criteria and Sub-Criteria}

The identified criteria and sub-criteria in Section 4.1 were categorized by experts into 6 main criteria and 21 sub-criteria. Based on the categorization and the results of the analytical survey in Table 6, we develop the hierarchy structure, as shown in Figure 2. The aim of the study is presented at the first level, the criteria and sub-criteria are presented at the second and third level, respectively. Level 4 is for the objective of research, which is the selection of sustainable suppliers using the fuzzy TOPSIS technique.

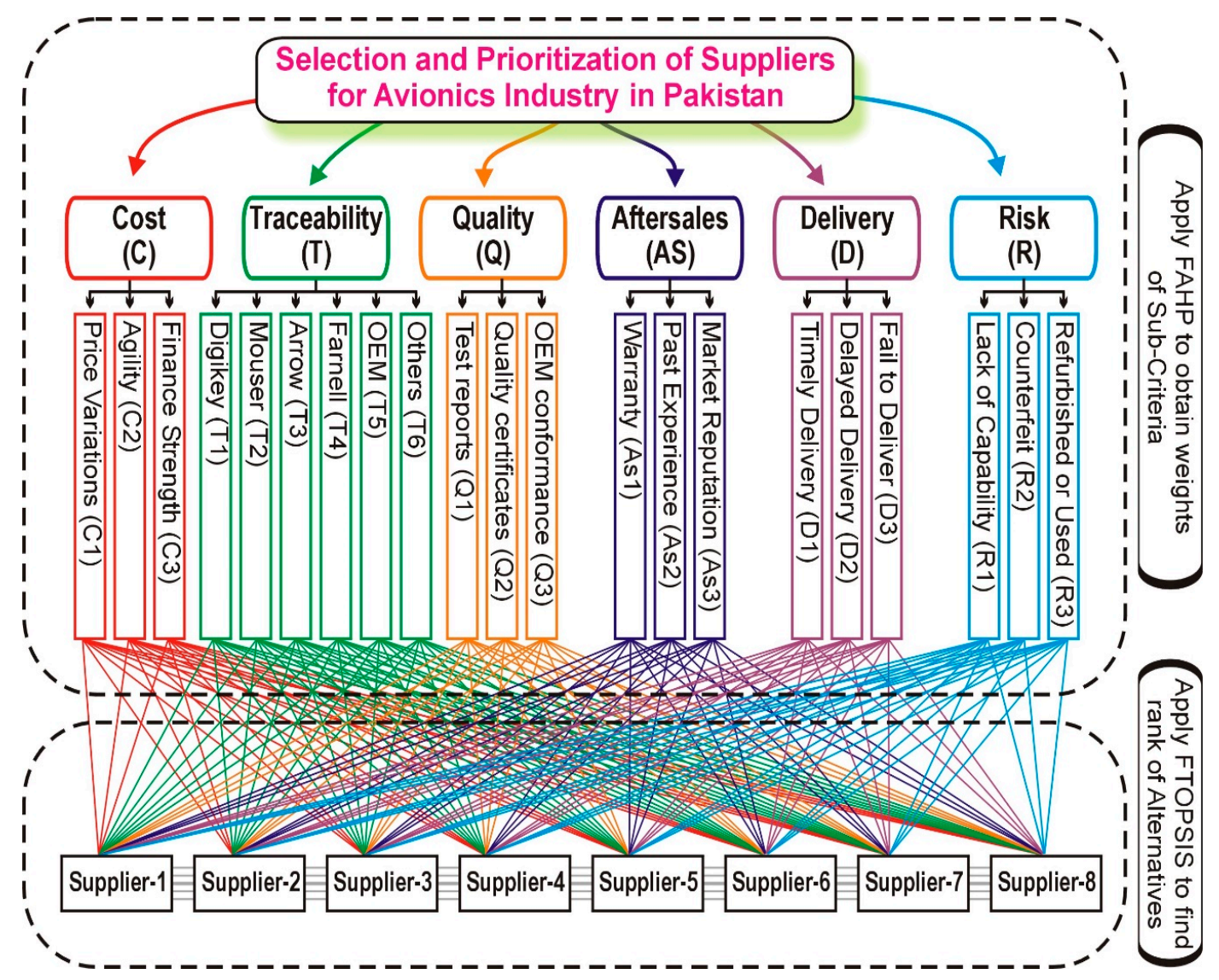

Figure 2. Selection and prioritization of suppliers for the avionics industry in Pakistan.

\subsubsection{Developing the Pairwise Comparison and Calculation of Priority Weights}

The evaluation and ranking of a suitable supplier is a complicated problem from the decision-making perspective. However, this attempt has been made to address the complicated decisions in the context of Pakistani industries. Therefore, this section consists of the results and analysis of this study. The key aim of this study is to explore and prioritize the criteria, sub-criteria, and their alternative using FAHP and then rank suppliers using the FTOPSIS. Experts from industry and academia calculate FAHP weights. The same 18 aexperts were again requested to provide priority weights to different criteria and sub-criteria based on their experience. Using these priority weights, we perform a pairwise comparison. The collected responses from the FAHP survey participants been transformed in the form of a geometric mean, aiming to determine the pairwise comparison of the criteria and sub-criteria. To convert the feedback of survey respondents into TFNs, the geometric mean methods were adopted. To calculate the geometric mean, the following formula was considered:

$$
\text { Geometric mean }=[(x 1)(x 2)(x 3) \ldots \ldots(x n)] 1 / n
$$$$
\mathrm{x}=\text { "Individual weight of each judgement" }
$$ 


$$
\mathrm{n}=\text { "Number of feedbacks." }
$$

The triangular fuzzy scales and their related linguistics variables are given in Table 4 . To determine the priority weights of criteria and their corresponding sub-criteria, the pairwise comparison was performed and their evaluation matrices were developed [78].

The study will select the most reliable supplier and will rank it according to established criteria. It will encourage suppliers (alternatives) to focus more on services, quality, and reliability rather than just being cheaper. Here, we have established different criteria and sub-criteria for supplier selections. These criteria and sub-criteria were analyzed using the FAHP method. Then, FTOPSIS was used to assess and prioritize the suppliers based on assessed criteria and sub-criteria. The Fuzzy TOPSIS results are provided in Appendix D, and the fuzzy pairwise comparison matrix of the main criteria and further detailed stepwise analysis are provided in Appendix E.

\subsubsection{The Main Criteria Results}

We developed the decision support framework for ranking suppliers based on different criteria and sub-criteria. A geometric mean approach has been employed in group decision-making [79]. Therefore, the experts were asked to perform a pairwise comparison matrix of the criteria, and sub-criteria based on the importance scale and analysis results are shown in Table 7 . The fuzzy pairwise comparison matrix of main criteria and further detailed stepwise analysis is presented in Appendix A. The determined priority weights indicated that traceability $(\mathrm{T})$ is the highest-ranked criterion, with a weight of 0.3449 for the supplier selection process. The quality $(\mathrm{Q})$ and $\operatorname{cost}(\mathrm{C})$ are declared as the second and third highest priority criteria, with a weight of 0.2473 and 0.1527 , respectively. The risk (R) criterion are considered as the fourth most significant criteria with a weight of 0.1221 . We also noted that the delivery (D) and after sales (AS), with a weight of 0.0882 and 0.0447 , are declared as the least significant criteria for the effective supplier selection process.

Table 7. Results of main criteria using the fuzzy analytical hierarchy process (FAHP) method.

\begin{tabular}{cccc}
\hline Code & Main Criteria & Weight & Rank \\
\hline $\mathrm{C}$ & Cost & 0.1527 & 3 \\
\hline $\mathrm{T}$ & Traceability & 0.3449 & 1 \\
\hline $\mathrm{Q}$ & Quality & 0.2473 & 2 \\
\hline $\mathrm{AS}$ & After sales & 0.0447 & 6 \\
\hline $\mathrm{D}$ & Delivery & 0.0882 & 5 \\
\hline $\mathrm{R}$ & Risk & 0.1221 & 4 \\
\hline
\end{tabular}

\subsubsection{Sub-Criteria Results}

By applying the FAHP approach, the local and global weights of each sub-criterion are determined. The pairwise comparison matrix of sub-criteria are given in Appendix C. The local rank renders the priority order of a sub-criteria within their corresponding main criteria. For example, the main criterion, 'Cost (C)', has three sub-criteria, i.e., C1, C2, and C3. The results show that Price Variation (C1), with a weight of 0.4150 , is ranked as the most significant sub-criterion in the cost $(\mathrm{C})$ main criterion (Table 8, Figure 3). Similarly, the local ranking of each sub-criterion was determined with the aim to check the priority order of each sub-criterion within their main criteria. Consequently, the final ranking or global ranking was determined with the aim to check the impact of each sub-criterion for the overall study objective. The global rank was determined by multiplying the weight of sub-criteria with their respective criteria (Figure 3, Table 8). For example, the global rank of $\mathrm{C} 1=0.4150 \times 0.1527=0.0634$, and based on the ranking order, $\mathrm{C} 1$ is ranked as the seventh-highest priority sub-criterion (Table 8). By considering the same method, the global ranks of each sub-criterion were determined. Using the calculated local and global ranking, the prioritization-based taxonomy of the criteria and sub-criteria is 
developed, which will assist the practitioners and researcher in considering the most significant criteria and their respective sub-criteria with respect to their interest and working area. Overall weights, local and global ranks of criteria, and sub-criteria are shown in Figure 3.

Table 8. Weights of criteria and sub-criteria.

\begin{tabular}{|c|c|c|c|c|c|c|c|}
\hline $\begin{array}{l}\text { Main } \\
\text { Criteria }\end{array}$ & $\begin{array}{l}\text { Weight of } \\
\text { Main } \\
\text { Criteria }\end{array}$ & Sub-Criteria & Code & $\begin{array}{c}\text { Priority } \\
\text { Weights of } \\
\text { Sub-Criteria }\end{array}$ & $\begin{array}{l}\text { Local } \\
\text { Rank } \\
\text { Rank }\end{array}$ & $\begin{array}{c}\text { Final } \\
\text { Weights }\end{array}$ & Rank \\
\hline \multirow{3}{*}{ Cost $(\mathrm{C})$} & \multirow{3}{*}{0.1527} & Price Variations & $\mathrm{C} 1$ & 0.4150 & 1 & 0.0634 & 07 \\
\hline & & Agility & $\mathrm{C} 2$ & 0.2970 & 2 & 0.0454 & 11 \\
\hline & & Financial Strength & C3 & 0.2890 & 3 & 0.0441 & 13 \\
\hline \multirow{6}{*}{$\begin{array}{c}\text { Traceability } \\
\text { (T) }\end{array}$} & \multirow{6}{*}{0.3449} & Digikey & $\mathrm{T} 1$ & 0.1832 & 5 & 0.0632 & 08 \\
\hline & & Mouser & $\mathrm{T} 2$ & 0.1891 & 2 & 0.0652 & 04 \\
\hline & & Arrow & $\mathrm{T} 3$ & 0.1903 & 1 & 0.0656 & 03 \\
\hline & & Farnell & $\mathrm{T} 4$ & 0.1885 & 3 & 0.0650 & 05 \\
\hline & & OEM & $\mathrm{T} 5$ & 0.1879 & 4 & 0.0648 & 06 \\
\hline & & Others & T6 & 0.0610 & 6 & 0.0210 & 17 \\
\hline \multirow{3}{*}{ Quality (Q) } & \multirow{3}{*}{0.2473} & Test Reports & Q1 & 0.5080 & 1 & 0.1256 & 01 \\
\hline & & Quality Certificates & Q2 & 0.2810 & 2 & 0.0695 & 02 \\
\hline & & $\begin{array}{l}\text { OEM Conformance } \\
\text { Certificates }\end{array}$ & Q3 & 0.2110 & 3 & 0.0522 & 09 \\
\hline \multirow{3}{*}{$\begin{array}{l}\text { Aftersales } \\
\text { (AS) }\end{array}$} & \multirow{3}{*}{0.0447} & Warranty & AS1 & 0.3940 & 1 & 0.0176 & 18 \\
\hline & & Previous Exp & AS2 & 0.2970 & 3 & 0.0133 & 21 \\
\hline & & Market Reputation & AS3 & 0.3090 & 2 & 0.0138 & 20 \\
\hline \multirow{3}{*}{ Risk (R) } & \multirow{3}{*}{0.1221} & Lack of capability & R1 & 0.3410 & 2 & 0.0416 & 14 \\
\hline & & Counterfeit & $\mathrm{R} 2$ & 0.3980 & 1 & 0.0486 & 10 \\
\hline & & Refurbished & $\mathrm{R} 3$ & 0.2610 & 3 & 0.0319 & 15 \\
\hline \multirow{3}{*}{$\begin{array}{l}\text { Delivery } \\
\text { (D) }\end{array}$} & \multirow{3}{*}{0.0882} & Timely delivery & D1 & 0.5130 & 1 & 0.0452 & 12 \\
\hline & & Delayed Delivery & D2 & 0.2900 & 2 & 0.0256 & 16 \\
\hline & & Fail To Deliver & D3 & 0.1970 & 3 & 0.0174 & 19 \\
\hline
\end{tabular}

\subsection{Fuzzy TOPSIS Results}

After the FAHP methodology for sustainable supplier selection using the criteria and sub-criteria, this section discusses the prioritization of eight suppliers using the fuzzy TOPSIS approach. The names of the supplier have not been mentioned in order to keep the secrecy of both supplier and avionics setup of Pakistan. The analysis by the group of experts in this study helped in constructing a fuzzy evaluation matrix into TFNs using linguistic variables. Thus, this study determined the evaluation matrix with respect to the alternatives. This followed the development of a fuzzy decision matrix, fuzzy normalized decision matrix, and weighted, normalized fuzzy decision matrix with regard to each factor in this study (see Appendix E). The ranking criteria and sub-criteria were subsequently assessed. Finally, the prioritized order of the eight suppliers has been obtained, as provided in Table 9. Researchers have used ANP, AHP, and FAHP methodologies to evaluate and rank suppliers [22,77]. However, here we employed both FAHP and FTOPSIS for sustainable supplier selection in the avionics industry of Pakistan. 


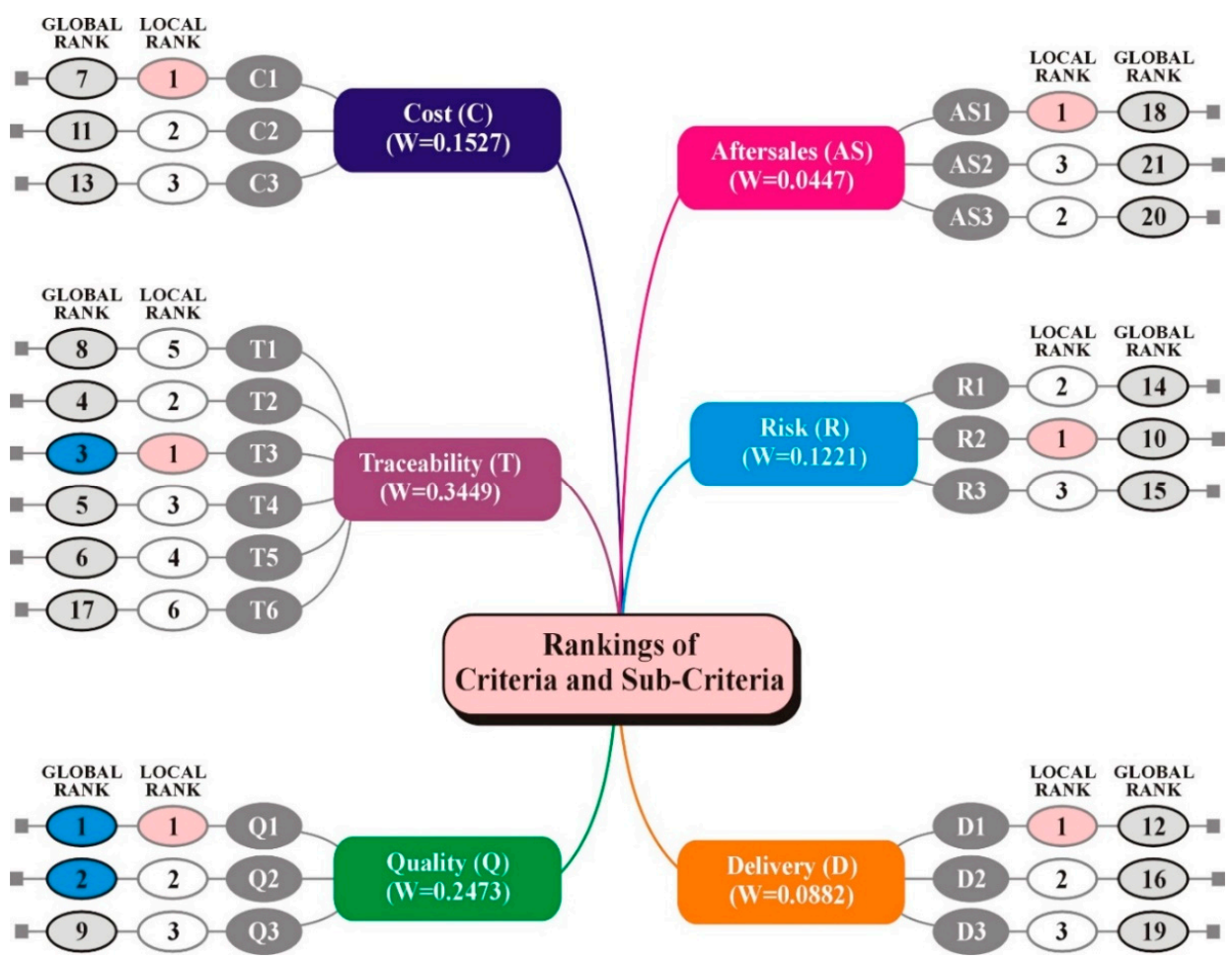

Figure 3. Ranking of criteria and sub-criteria for supplier selection.

Table 9. The final ranking of suppliers (alternatives).

\begin{tabular}{ccccccc}
\hline Code & Alternative & $\mathbf{d}^{+}$ & $\mathbf{d}^{-}$ & $\mathbf{C C}_{\mathbf{i}}$ & Normalize $\mathbf{C C}_{\mathbf{i}}$ & Final Ranking \\
\hline S1 & Supplier-1 & 8.0375 & 12.2541 & 0.6039 & 0.143 & 3 \\
\hline S2 & Supplier-2 & 5.3257 & 15.0308 & 0.7384 & 0.174 & 2 \\
\hline S3 & Supplier-3 & 8.7474 & 11.3303 & 0.5643 & 0.133 & 5 \\
\hline S4 & Supplier-4 & 10.1567 & 10.0182 & 0.4966 & 0.117 & 6 \\
\hline S5 & Supplier-5 & 8.3404 & 12.0072 & 0.5901 & 0.139 & 4 \\
\hline S6 & Supplier-6 & 15.8054 & 4.1233 & 0.2069 & 0.049 & 7 \\
\hline S7 & Supplier-7 & 16.9217 & 3.3261 & 0.1643 & 0.039 & 8 \\
\hline S8 & Supplier-8 & 2.5388 & 17.3913 & 0.8726 & 0.206 & 1 \\
\hline
\end{tabular}

From Table 9, we conclude that the final ranking of supplier is Supplier $8>$ Supplier $2>$ Supplier $1>$ Supplier $5>$ Supplier $3>$ Supplier $4>$ Supplier $6>$ Supplier 7. All experts' opinions and criteria finally provide us with this ranking. The ranking is not based on a single criterion, but it has considered all criteria and sub-criteria. For any further investigation of supplier performance evaluation or selection, we can jointly study these rankings with our required criteria and sub-criteria. We may select different suppliers relative to the requirement of supplies. This is an overall ranking for a list of suppliers evaluated under the required main and sub-criteria. For some particular cases, a supplier may be selected by ignoring the overall ranking. For example, if a supplier is an authorized dealer of some particular brand, even it falls low in the criteria, in that particular case, he is the optimum choice.

\subsection{Sensitivity Analysis}

The sensitivity analysis is undertaken to evaluate the robustness of the obtained results in this study; for instance, to analyze how the new ranking of alternatives evolves while the criteria weights are varied. In this context, 14 cases were developed and evaluated by varying the weights to measure 
the final result/priority of the suppliers. The varying weights of criteria under these 14 cases are presented in Table 10. The actual weights of the criteria remained the same in case-1, while 13 other cases were analyzed by changing the weights under the sensitivity analysis. It is evident that in the majority of the cases, the criteria weights remained the same. Finally, the ranking of the suppliers based on 14 cases of sensitivity analysis is given in Table 11 and Figure 4. Supplier-8, supplier-2, and supplier-1 remained the important suppliers in the avionic industry of Pakistan. It is found in these analyses that the ranking of the priority order of the suppliers remained the same in most cases.

Table 10. Sensitivity analysis.

\begin{tabular}{ccccccccccccccc}
\hline Criteria & $\begin{array}{c}\text { Case (C)-1 } \\
\text { (Actual) }\end{array}$ & C-2 & C-3 & C-4 & C-5 & C-6 & C-7 & C-8 & C-9 & C-10 & C-11 & C-12 & C-13 & C-14 \\
\hline C & 0.1527 & 0.167 & 0.300 & 0.140 & 0.140 & 0.140 & 0.140 & 0.140 & 0.500 & 0.100 & 0.100 & 0.100 & 0.100 & 0.100 \\
\hline T & 0.3449 & 0.167 & 0.140 & 0.300 & 0.140 & 0.140 & 0.140 & 0.140 & 0.100 & 0.500 & 0.100 & 0.100 & 0.100 & 0.100 \\
\hline Q & 0.2473 & 0.167 & 0.140 & 0.140 & 0.300 & 0.140 & 0.140 & 0.140 & 0.100 & 0.100 & 0.500 & 0.100 & 0.100 & 0.100 \\
\hline AS & 0.0447 & 0.167 & 0.140 & 0.140 & 0.140 & 0.300 & 0.140 & 0.140 & 0.100 & 0.100 & 0.100 & 0.500 & 0.100 & 0.100 \\
\hline R & 0.1221 & 0.167 & 0.140 & 0.140 & 0.140 & 0.140 & 0.300 & 0.140 & 0.100 & 0.100 & 0.100 & 0.100 & 0.500 & 0.100 \\
\hline D & 0.0882 & 0.167 & 0.140 & 0.150 & 0.140 & 0.140 & 0.140 & 0.300 & 0.100 & 0.100 & 0.100 & 0.100 & 0.100 & 0.500 \\
\hline
\end{tabular}

Table 11. Ranking under different cases.

\begin{tabular}{ccccccccccccccc}
\hline Alternative & Case-1 & C-2 & C-3 & C-4 & C-5 & C-6 & C-7 & C-8 & C-9 & C-10 & C-11 & C-12 & C-13 & C-14 \\
\hline S1 & 3 & 3 & 3 & 3 & 3 & 3 & 3 & 3 & 2 & 3 & 4 & 3 & 3 & 3 \\
\hline S2 & 2 & 2 & 2 & 2 & 2 & 2 & 2 & 2 & 3 & 1 & 2 & 2 & 2 & 2 \\
\hline S3 & 5 & 5 & 5 & 5 & 5 & 5 & 5 & 5 & 5 & 5 & 3 & 5 & 5 & 5 \\
\hline S4 & 6 & 6 & 6 & 6 & 6 & 6 & 6 & 6 & 6 & 6 & 6 & 4 & 6 & 6 \\
\hline S5 & 4 & 4 & 4 & 4 & 4 & 4 & 4 & 4 & 4 & 4 & 5 & 6 & 4 & 4 \\
\hline S6 & 7 & 7 & 7 & 7 & 7 & 7 & 7 & 7 & 7 & 7 & 7 & 7 & 8 & 7 \\
\hline S7 & 8 & 8 & 8 & 8 & 8 & 8 & 8 & 8 & 8 & 8 & 8 & 8 & 7 & 8 \\
\hline S8 & 1 & 1 & 1 & 1 & 1 & 1 & 1 & 1 & 1 & 2 & 1 & 1 & 1 & 1 \\
\hline
\end{tabular}

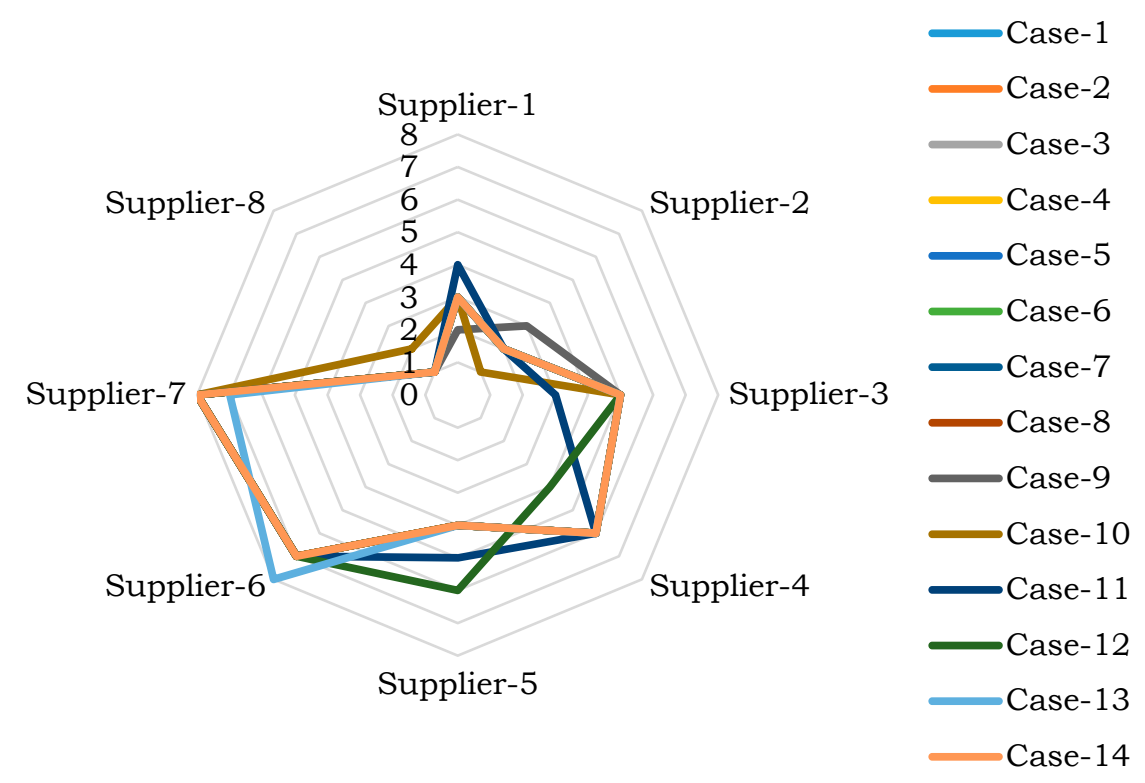

Figure 4. Sensitivity analysis-ranking under different cases. 


\subsection{Results Summary}

The results give a complete methodology for decision making by removing human error and biases for high-tech applications. The above study can be used in the military and avionics industries of developing countries. The study contributed by providing the state-of-the-art criteria and sub-criteria reported in the literature and the insight of the experts. These in-depth reviews and empirical investigations provide a vast knowledge of the criteria and sub-criteria that need to be focused on by the industry experts and researchers. In addition, the FAHP analysis provides the rank order of the criteria and their respective sub-criteria that will assist the practitioners and researchers in considering the most significant criteria concern to their working area and interest. The fuzzy TOPSIS analysis provides a rational bias-free scientific approach for supplier selection, which can further be refined by data logging about supplier performance for the next few years. The results provide a new criterion which incorporates more important factors for product reliability along with the cost. The continuous learning process and availability of traceable record will further refine the alternatives as a system of continuous performance monitoring is established.

\section{Conclusions}

The avionics industry of Pakistan entirely relies on the sustainable supply of electronic components from different suppliers. As the reliability of the product primarily depends upon the authenticity of the source, the supplier and product lifecycle support are linked to the sustainability of the supply chain and supplier. Thus, concerns about the effectiveness and rationality of the critical task of sustainable supplier selection for the purchase of reliable and original electronic components have become central to the decision-makers of the avionics industry of Pakistan. The study originated from the inevitable failures of products that lead to carrying out root cause analysis. Finally, it was revealed that failure occurred due to low quality and counterfeit electronic components. This raised questions on procurement procedures for the industry, which were relying mostly on cost and pre-qualification of registered suppliers. The unavailability of parts for lifecycle support exposed the sustainability of the supply chain and the presence of opportunist suppliers.

This study proposes a novel method for addressing supplier selection issues based on sustainability and reliability rather than cost. Due to human bias and links of suppliers, it was decided to build decision criteria based on feedback from technical experts. To make it unbiased, handle inconsistencies, and make it error-prone, we used the FAHP and FTOPSIS techniques. From the analysis of initial inputs from experts and decision-makers, it was concluded with results and discussion that the newly developed criteria give more weight to reliability and quality instead of cost and deliveries. The methodology is flexible and can be used for continuously upgrading and evaluating the alternatives (suppliers); it can also adopt any additional criteria and sub-criteria in the real-time environment. This study about the Pakistan avionics industry is carried out for the first time; the study can accommodate more parameters for selection criteria.

The study has covered almost all types of criteria explored from the literature or by experts. Nevertheless, it can identify more criteria, or it can be modified to address other similar issues. For future work, other MCDM methods can also be used, such as VIKOR, ANP, ELECTRE, and DEMATEL, to compare the results of the current study and determine the feasibility of other MCDM methods. Since every MCDM method has its own functions and steps to perform and solve the decision-problem. Further, for uncertainties and missing data, we can combine our methodology with gray prediction theory to eliminate the uncertainty and obtain more reliable results. Due to the limited number of suppliers, we can work on sustainable supplier development tools and criteria in the future for the better support of the avionics industry.

Author Contributions: The following research activities were performed by specific authors: conceptualization, N.M. and Z.F.; methodology, N.M., M.A.A.; Formal Analysis, N.M., S.A.A.S., and Y.A.S.; Validation N.M. Z.F. and A.A. resources and data curation N.M., S.A.A.S. and M.A.A.; funding, A.A. and A.G.; supervision, Z.F.; writing 
original draft, N.M.; review and editing, N.M., Z.F., A.A., S.A.A.S. and Y.A.S.; project administration by Z.F. and A.A. All authors have read and agreed to the published version of the manuscript.

Acknowledgments: The authors are grateful to the Deanship of Scientific Research, King Saud University, for funding through the Vice Deanship of Scientific Research Chairs.

Conflicts of Interest: The authors declare no conflict of interest.

\section{Appendix A}

Sample of Survey Questionnaire (https://tinyurl.com/r52a4xu).

\section{Appendix B}

Demographic information of survey respondents (https://tinyurl.com/r28s5ua).

\section{Appendix C}

Pairwise comparison matrices (https://tinyurl.com/rjeqxwo).

\section{Appendix D}

Fuzzy TOPSIS results (https://tinyurl.com/vmgaae7).

\section{Appendix E}

The fuzzy pairwise comparison matrix of main criteria and further detailed stepwise analysis (https://tinyurl.com/yac9xo72).

Appendix A-E: Combined Appendices (https://tinyurl.com/ybclectt).

\section{References}

1. Blum, J. Arms production, national defense spending and arms trade: Examining supply and demand. Eur. J. Polit. Econ. 2019, 101814. [CrossRef]

2. Gullo, L.J. Organizational Reliability Capability Assessment. Des. Reliab. 2012, 29, 267-284. [CrossRef]

3. Stradley, J; Karraker, D. The electronic part supply chain and risks of counterfeit parts in defense applications. IEEE Trans. Components Packag. Technol. 2006, 29, 703-705. [CrossRef]

4. Guin, U.; Huang, K.; Dimase, D.; Carulli, J.M.; Tehranipoor, M.; Makris, Y. Counterfeit integrated circuits: A rising threat in the global semiconductor supply chain. Proc. IEEE 2014, 102, 1207-1228. [CrossRef]

5. Mura, G. Reliability concerns from the gray market. Microelectron. Reliab. 2018, 88-90, 26-30. [CrossRef]

6. Regis, D.; Hubert, G.; Bayle, F.; Gatti, M. IC components reliability concerns for avionics end-users. In Proceedings of the 2013 IEEE/AIAA 32nd Digital Avionics Systems Conference (DASC), East Syracuse, NY, USA, 5-10 October 2013; pp. 2C2-1-2C2-9. [CrossRef]

7. Bechtold, L.E.; Moliere, F.; Sunderland, D.A.; Tawfellos, B. Practical applications of semiconductor reliability modeling. In Proceedings of the 2015 Annual Reliability and Maintainability Symposium (RAMS), Palm Harbor, FL, USA, 26-29 January 2015. [CrossRef]

8. Sinha, P.R.; Whitman, L.E.; Malzahn, D. Methodology to mitigate supplier risk in an aerospace supply chain. Supply Chain Manag. 2004, 9, 154-168. [CrossRef]

9. Azimifard, A.; Moosavirad, S.H.; Ariafar, S. Selecting sustainable supplier countries for Iran's steel industry at three levels by using AHP and TOPSIS methods. Resour. Policy 2018, 57, 30-44. [CrossRef]

10. Jain, V.; Sangaiah, A.K.; Sakhuja, S.; Thoduka, N.; Aggarwal, R. Supplier selection using fuzzy AHP and TOPSIS: A case study in the Indian automotive industry. Neural Comput. Appl. 2018, 29, 555-564. [CrossRef]

11. Dweiri, F.; Kumar, S.; Khan, S.A.; Jain, V. Designing an integrated AHP based decision support system for supplier selection in automotive industry. Expert Syst. Appl. 2016, 62, 273-283. [CrossRef]

12. Kilincci, O.; Onal, S.A. Fuzzy AHP approach for supplier selection in a washing machine company. Expert Syst. Appl. 2011, 38, 9656-9664. [CrossRef]

13. Lin, C.; Hung, K.; Hu, S. A Decision-Making Model for Evaluating and Selecting Suppliers for the Sustainable Operation and Development of Enterprises in the Aerospace Industry. Sustainability 2018, 10, 735. [CrossRef] 
14. Chen, Z.; Yang, W. An MAGDM based on constrained FAHP and FTOPSIS and its application to supplier selection. Math. Comput. Model. 2011, 54, 2802-2815. [CrossRef]

15. Zadeh, L.A. Fuzzy sets as a basis for a theory of possibility. Fuzzy Sets Syst. 1978, 1, 3-28. [CrossRef]

16. Sinha, A.K.; Anand, A. Development of sustainable supplier selection index for new product development using multi criteria decision making. J. Clean. Prod. 2018, 197, 1587-1596. [CrossRef]

17. Jain, R.; Yadav, H.C.; Singh, A.R.; Mishra, P.K. Using data mining synergies for evaluating criteria at pre-qualification stage of supplier selection. J. Intell. Manuf. 2014, 165-175. [CrossRef]

18. Xu, Z.; Qin, J.; Liu, J.; Martínez, L. Sustainable supplier selection based on AHPSort II in interval type-2 fuzzy environment. Inf. Sci. 2019, 483, 273-293. [CrossRef]

19. Sirisawat, P.; Kiatcharoenpol, T. Computers \& Industrial Engineering Fuzzy AHP-TOPSIS approaches to prioritizing solutions for reverse logistics barriers. Comput. Ind. Eng. 2018, 117, 303-318. [CrossRef]

20. Alikhani, R.; Torabi, S.A.; Altay, N. Strategic supplier selection under sustainability and risk criteria. Int. J. Prod. Econ. 2019, 208, 69-82. [CrossRef]

21. Memari, A.; Dargi, A.; Akbari Jokar, M.R.; Ahmad, R.; Abdul Rahim, A.R. Sustainable supplier selection: A multi-criteria intuitionistic fuzzy TOPSIS method. J. Manuf. Syst. 2019, 50, 9-24. [CrossRef]

22. Chamodrakas, I.; Batis, D.; Martakos, D. Expert Systems with Applications Supplier selection in electronic marketplaces using satisficing and fuzzy AHP. Expert Syst. Appl. 2010, 37, 490-498. [CrossRef]

23. Settanni, E.; Thenent, N.E.; Newnes, L.B.; Parry, G.; Goh, Y.M. Mapping a product-service-system delivering defence avionics availability. Int. J. Prod. Econ. 2017, 186, 21-32. [CrossRef]

24. Lintukangas, K.; Kähkönen, A.-K.; Hallikas, J. The role of supply management innovativeness and supplier orientation in firms' sustainability performance. J. Purch. Supply Manag. 2019, 25, 100558. [CrossRef]

25. Gören, H.G. A decision framework for sustainable supplier selection and order allocation with lost sales. J. Clean. Prod. 2018, 183, 1156-1169. [CrossRef]

26. Fu, Y.K. An integrated approach to catering supplier selection using AHP-ARAS-MCGP methodology. J. Air Transp. Manag. 2019, 75, 164-169. [CrossRef]

27. Dožić, S. Multi-criteria decision making methods: Application in the aviation industry. J. Air Transp. Manag. 2019, 79. [CrossRef]

28. Shah, S.A.A.; Zhou, P.; Walasai, G.D.; Mohsin, M. Energy security and environmental sustainability index of South Asian countries: A composite index approach. Ecol. Indic. 2019, 106, 105507. [CrossRef]

29. Wang, Y.; Shah, S.A.A.; Zhou, P. City-level environmental performance in China. Energy Ecol. Environ. 2018, 3, 149-161. [CrossRef]

30. Karsak, E.E.; Dursun, M. An integrated fuzzy MCDM approach for supplier evaluation and selection. Comput. Ind. Eng. 2015, 82, 82-93. [CrossRef]

31. Bruno, G.; Esposito, E.; Genovese, A. A model for aircraft evaluation to support strategic decisions. Expert Syst. Appl. 2015, 42, 5580-5590. [CrossRef]

32. Jiang, H. Service quality of low-cost long-haul airlines - The case of Jetstar Airways and AirAsia X. J. Air Transp. Manag. 2013, 26, 20-24. [CrossRef]

33. Sun, C.C. A performance evaluation model by integrating fuzzy AHP and fuzzy TOPSIS methods. Expert Syst. Appl. 2010, 37, 7745-7754. [CrossRef]

34. Solangi, Y.A.; Tan, Q.; Mirjat, N.H.; Ali, S. Evaluating the strategies for sustainable energy planning in Pakistan: An integrated SWOT-AHP and Fuzzy-TOPSIS approach. J. Clean. Prod. 2019, 236, 117655. [CrossRef]

35. Shah, S.A.A. Feasibility study of renewable energy sources for developing the hydrogen economy in Pakistan. Int. J. Hydrogen Energy 2019, 45, 15841-15854. [CrossRef]

36. Lima Junior, F.R.; Osiro, L.; Carpinetti, L.C.R. A comparison between Fuzzy AHP and Fuzzy TOPSIS methods to supplier selection. Appl. Soft Comput. J. 2014, 21, 194-209. [CrossRef]

37. Solangi, Y.A.; Shah, S.A.A.; Zameer, H.; Ikram, M.; Saracoglu, B.O. Assessing the solar PV power project site selection in Pakistan: Based on AHP-fuzzy VIKOR approach. Environ. Sci. Pollut. Res. 2019. [CrossRef] [PubMed]

38. Musaad, O.; Sultan, A.; Zhuo, Z.; Musaad, O.; Otaibi, A.; Siyal, Z.A.; Hashmi, H.; Shah, S.A.A. A Fuzzy Multi-Criteria Analysis of Barriers and Policy Strategies for Small and Medium Enterprises to Adopt Green Innovation. Symmetry 2020, 12, 116. [CrossRef] 
39. Konys, A. Green supplier selection criteria: From a literature review to a comprehensive knowledge base. Sustainability 2019, 11, 4208. [CrossRef]

40. Govindan, K.; Rajendran, S.; Sarkis, J.; Murugesan, P. Multi criteria decision making approaches for green supplier evaluation and selection: A literature review. J. Clean. Prod. 2015, 98, 66-83. [CrossRef]

41. Wang Chen, H.M.; Chou, S.Y.; Luu, Q.D.; Yu, T.H.K. A Fuzzy MCDM Approach for Green Supplier Selection from the Economic and Environmental Aspects. Math. Probl. Eng. 2016, 2016. [CrossRef]

42. Zhuo, Z.; Siyal, Z.A.; Shaikh, G.M.; Shah, S.A.A.; Solangi, Y.A. An Integrated Multi-Criteria Decision Support Framework for the Selection of Suppliers in Small and Medium Enterprises based on Green Innovation Ability. Processes 2020, 8, 418.

43. Rezaei, J.; Nispeling, T.; Sarkis, J.; Tavasszy, L. A supplier selection life cycle approach integrating traditional and environmental criteria using the best worst method. J. Clean. Prod. 2016, 135, 577-588. [CrossRef]

44. Zafar, A.; Zafar, M.; Sarwar, A.; Raza, H.; Khan, M.T. A Fuzzy AHP Method for Green Supplier Selection and Evaluation. In Proceedings of the International Conference on Management Science and Engineering Management; Springer: Berlin, Germany, 2019; pp. 1355-1366.

45. Sharma, D.G.; Rawani, A.M. Green Supplier Selection for Indian Cement Industry: AHP based approach. Int. Res. J. Eng. Technol. 2016, 3, 2368-2373.

46. Prakash, C.; Barua, M.K. An analysis of integrated robust hybrid model for third-party reverse logistics partner selection under fuzzy environment. Resour. Conserv. Recycl. 2016, 108, 63-81. [CrossRef]

47. Luthra, S.; Govindan, K.; Kannan, D.; Mangla, S.K.; Garg, C.P. An integrated framework for sustainable supplier selection and evaluation in supply chains. J. Clean. Prod. 2017, 140, 1686-1698. [CrossRef]

48. Tsui, C.W.; Wen, U.P. A hybrid multiple criteria group decision-making approach for green supplier selection in the TFT-LCD industry. Math. Probl. Eng. 2014, 2014. [CrossRef]

49. Demirtaş, N.; Özgürler, Ş.; Özgürler, M.; Güneri, A.F. Selecting e-purse smart card technology via fuzzy AHP and ANP. J. Appl. Math. 2014, 2014. [CrossRef]

50. Yücenur, G.N.; Vayvay, Ö.; Demirel, N.Ç. Supplier selection problem in global supply chains by AHP and ANP approaches under fuzzy environment. Int. J. Adv. Manuf. Technol. 2011, 56, 823-833. [CrossRef]

51. Chang, S.C.; Lin, C.F.; Wu, W.M. The features and marketability of certificates for occupational safety and health management in Taiwan. Saf. Sci. 2016, 85, 77-87. [CrossRef]

52. Wang, X. A comprehensive decision making model for the evaluation of green operations initiatives. Technol. Forecast. Soc. Change 2015, 95, 191-207. [CrossRef]

53. Jothimani, D.; Sarmah, S.P. Supply chain performance measurement for third party logistics. Benchmarking 2014. [CrossRef]

54. Mishra, A.R.; Rani, P.; Pardasani, K.R.; Mardani, A. A novel hesitant fuzzy WASPAS method for assessment of green supplier problem based on exponential information measures. J. Clean. Prod. 2019, 238. [CrossRef]

55. Oroojeni Mohammad Javad, M.; Darvishi, M. Green Supplier Selection for the Steel Industry Using BWM and Fuzzy TOPSIS: A case study of Khouzestan Steel Company. Sustain. Futur. 2020, 100012. [CrossRef]

56. Jiang, P.; Hu, Y.C.; Yen, G.F.; Tsao, S.J. Green supplier selection for sustainable development of the automotive industry using grey decision-making. Sustain. Dev. 2018, 26, 890-903. [CrossRef]

57. Önüt, S.; Kara, S.S.; Işik, E. Long term supplier selection using a combined fuzzy MCDM approach: A case study for a telecommunication company. Expert Syst. Appl. 2009, 36, 3887-3895. [CrossRef]

58. Krause, D.R.; Ellram, L.M.; Routroy, S.; Pradhan, S.K. Evaluating the critical success factors of supplier development: A case study. Benchmarking Int. J. 1997, 20, 322-341.

59. Zeydan, M.; Çolpan, C.; Çobanoǵlu, C. A combined methodology for supplier selection and performance evaluation. Expert Syst. Appl. 2011, 38, 2741-2751. [CrossRef]

60. Opricovic, S.; Tzeng, G.H. Compromise solution by MCDM methods: A comparative analysis of VIKOR and TOPSIS. Eur. J. Oper. Res. 2004, 156, 445-455. [CrossRef]

61. Lin, Y.; Lin, C.; Yu, H.; Tzeng, G. Expert Systems with Applications A novel hybrid MCDM approach for outsourcing vendor selection: A case study for a semiconductor company in Taiwan. Expert Syst. Appl. 2010, 37, 4796-4804. [CrossRef]

62. Yu, J.R.; Tsai, C.C. A decision framework for supplier rating and purchase allocation: A case in the semiconductor industry. Comput. Ind. Eng. 2008, 55, 634-646. [CrossRef]

63. Lin, C.T.; Chen, C.B.; Ting, Y.C. An ERP model for supplier selection in electronics industry. Expert Syst. Appl. 2011, 38, 1760-1765. [CrossRef] 
64. Miller, M.; Meraglia, J.; Hayward, J. Traceability in the Age of Globalization: A Proposal for a Marking Protocol to Assure Authenticity of Electronic Parts. SAE Tech. Pap. 2012. [CrossRef]

65. Taherdoost, H.; Brard, A. Analyzing the Process of Supplier Selection Criteria and Methods. Procedia Manuf. 2019, 32, 1024-1034. [CrossRef]

66. Kilic, H.S. An integrated approach for supplier selection in multi-item / multi-supplier environment. Appl. Math. Model. 2013, 37, 7752-7763. [CrossRef]

67. Zhang, Y.; Ieee, S.M.; Guin, U.; Ieee, M. End-to-End Traceability of ICs in Component Supply Chain for Fighting Against Recycling. IEEE Trans. Inf. Forensics Secur. 2019. [CrossRef]

68. Trojans, H. Integrated Circuit Authentication; Springer: Manhattan, NY, USA, 2013; ISBN 9783319008158.

69. Lau, H.; Nakandala, D.; Samaranayake, P.; Shum, P. A hybrid multi-criteria decision model for supporting customerfocused profitability analysis. Ind. Manag. Data Syst. 2016, 116, 1105-1130. [CrossRef]

70. Dahel, N.E. Vendor selection and order quantity allocation in volume discount environments. Supply Chain Manag. 2003, 8, 335-342. [CrossRef]

71. Song, T.; Li, Y.; Song, J.; Zhang, Z. Airworthiness considerations of supply chain management from Boeing 787 Dreamliner battery issue. Procedia Eng. 2014, 80, 628-637. [CrossRef]

72. Dusek, G.A.; Yurova, Y.V.; Ruppel, C.P. Using social media and targeted snowball sampling to survey a hard-to-reach population: A case study. Int. J. Dr. Stud. 2015, 10, 279-299. [CrossRef]

73. Naderifar, M.; Goli, H.; Ghaljaie, F. Snowball Sampling: A Purposeful Method of Sampling in Qualitative Research. Strides Dev. Med. Educ. 2017, 14. [CrossRef]

74. Kong, F.; Liu, H. Applying fuzzy analytic hierarchy process to evaluate success factors of e-commerce. Int. J. Inf. Syst. Sci. 2005, 1, 406-412.

75. Shah, S.A.A.; Solangi, Y.A.; Ikram, M. Analysis of barriers to the adoption of cleaner energy technologies in Pakistan using Modified Delphi and Fuzzy Analytical Hierarchy Process. J. Clean. Prod. 2019. [CrossRef]

76. Xu, L.; Shah, S.A.A.; Zameer, H.; Solangi, Y.A. Evaluating renewable energy sources for implementing the hydrogen economy in Pakistan: A two-stage fuzzy MCDM approach. Environ. Sci. Pollut. Res. 2019. [CrossRef] [PubMed]

77. Akbar, M.A.; Nasrullah; Shameem, M.; Ahmad, J.; Maqbool, A.; Abbas, K. Challenging factors of Requirements Change. In Proceedings of the 2018 International Conference on Computing, Electronic and Electrical Engineering (ICE Cube), Quetta, Pakistan, 12-13 November 2018; Volume 37, pp. 1-7.

78. Solangi, Y.; Tan, Q.; Khan, M.; Mirjat, N.; Ahmed, I. The Selection of Wind Power Project Location in the Southeastern Corridor of Pakistan: A Factor Analysis, AHP, and Fuzzy-TOPSIS Application. Energies 2018, 11, 1940. [CrossRef]

79. Junaid, M.; Xue, Y.; Syed, M.W.; Li, J.Z.; Ziaullah, M. A Neutrosophic AHP and TOPSIS Framework for Supply Chain Risk Assessment in Automotive Industry of Pakistan. Sustainability 2019, 12, 154. [CrossRef] 